\title{
Relationship between Online Game Addiction with Depression in Adolescents from 6 High Schools in Indonesia
}

\author{
Nikson Sitorus ${ }^{1}$, Prisca P. Arfines ${ }^{1} \&$ Indri Y. Suryaputri ${ }^{1}$ \\ ${ }^{1}$ Center for Research and Development of Public Health Efforts, NIHRD, Ministry of Health of Indonesia, \\ Indonesia \\ Correspondence: Nikson Sitorus, Center for Research and Development of Public Health Efforts, NIHRD, \\ Ministry of Health of Indonesia, Jl. Percetakan Negara 29 Jakarta 10560, Indonesia. Tel: 62-21-4287-2392. E-mail: \\ nikson.sitorus@litbang.kemkes.go.id
}

Received: August 20, 2020 Accepted: October 1, 2020 Online Published: October 19, 2020

doi:10.5539/gjhs.v12n12p43 URL: https://doi.org/10.5539/gjhs.v12n12p43

\begin{abstract}
The World Health Organization (WHO) has defined online game addiction into one of the medical conditions in 2018 under the category of Gaming disorder. Playing online games excessively may be related to both physical and psychological health. The problem of online game addiction and its impact on adolescent's mental health is still not sufficiently documented. This study aimed to analyze the relationship between online game addiction and depression in adolescents from 6 High Schools in 4 districts/cities of Indonesia. This study is a quantitative research with cross-sectional design as a further analysis of the 2019 School-Based Mental Health Intervention Study. This study involved students of grade 10 and 11 at 6 public high schools in Bogor Regency, Bogor City, City of Central and South Jakarta. The statistical analysis used was multiple logistic regression test. Out of 746 students, $12.9 \%$ were depressed and $10.3 \%$ were addicted to online games. There was a significant relationship between online game addiction towards depression with $\mathrm{OR}=2.44$ (95\% CI: 1.259-4.735) after being controlled for sex, learning difficulties, age, father's education, and mother's education. Schools are the best institutions that can be used for adolescent depression screening. It is expected that provision of mental health service facilities in school as one of the strategies to overcome online gaming addictions.
\end{abstract}

Keywords: game online, addiction, depression, adolescent, student, Indonesia

\section{Introduction}

The development of technology and information has driven the increasing use of online games globally, including Indonesia. The online game is defined as a game played by many players interconnected through the internet network. Certain types of are games available on the internet but do not require a connection to play are also counted in the category of online games (Adams, 2009). The devices to play online games include a computer, a handheld device, or a video game console (Jap, Tiatri, Jaya, \& Suteja, 2013).

The World Health Organization has officially included online gaming addiction into one of the medical conditions in 2018, under the category of Gaming disorder. Gaming disorders fall into the category of mental disorders in the International Classification of Diseases (ICD-11) for increasing the priority in playing the online game compared to other activities. This behavioral addiction continues to increase even though the individual aware of the negative impact (World Health Organization, 2018).

There have been many studies examining the prevalence of internet gaming disorder (IGD) worldwide. This IGD not only covers problems caused by online games but also includes offline games. However, most of which cause addiction to play is an online game with a type of Massively Multiplayer Online Role-Playing Game (MMORPG) (Gentile et al., 2017). A meta-analysis study in 2018 summarizes the magnitude of the prevalence of IGDs in the past 3 decades by $4.1 \%$ from a total of 28 studies from around the world (Fam, 2018). Besides, other studies reveal the prevalence of IGDs varies in the range between 1\%-9\% depending on the age of the respondent, country, and other sample characteristics (Gentile et al., 2017). The prevalence of IGD for rural adolescents living in a province in Thailand in 2018 was 5.4\% (Taechoyotin, Tongrod, Thaweerungruangkul, \& Towattananon, 2020). The prevalence of online game addiction in Indonesia has not been well documented. Most studies were conducted with a relatively small number of samples. The pilot study in developing the Indonesian online game addiction questionnaire found an estimated prevalence of online game addiction by $10.15 \%$ in school students (Jap et al., 
2013).

Compared to adulthood, adolescents are considered more often and more susceptible to online game addiction (Kuss \& Griffiths, 2012). They are adolescents who are in a transition period biologically, psychosocially, and economically with health risk behaviors. Both adolescent males and females may use online games as a coping effort against stress. Previous research has proven the relationship of addiction to online games with sensation-seeking behavior to reach new experiences and be uplifting (Hu, Zhen, Yu, Zhang, \& Zhang, 2017).

A model developed from clinical research found that adolescent with IGD has a unique set of maladaptive beliefs. It underlies excessive play in online games including (a) beliefs about the value of prizes in games and reality, (b) rigid and maladaptive rules for playing the games, (c) overly relying on games to meet the need for self-esteem, and (d) games as a method of gaining social acceptance (D. L. King \& Delfabbro, 2014). In addition, the role of peers holds an important key to the behavior of playing online games. Research in Bali shows the role of peers as a motivating factor for adolescents playing online games (Wiguna \& Herdiyanto, 2018).

Adolescents who are addicted to online games are found to have low motivation to engage in academic pursuits, spend more time to play, often play truant, have low academic grades, and experience sleep problems (D. King \& Delfabbro, 2018), (Jannah \& Nirwana, 2015), (Lam, 2014; Manuputty et al., 2019). For this, a systematic review proved that playing excessive online games especially MMORPG types is associated with poor sleep quality and short sleep duration (Lam, 2014). Studies in Indonesia also get similar result (Manuputty et al., 2019). A study in France in 2011 found the effects of online game addiction on sleep habits, mood disorders, and physical and psychological health problems. An online game addict has a greater risk of experiencing deeper, more sensitive sadness, and greater physical and psychological health than non-addicts (Achab et al., 2011). Additionally to the risk, social interaction with family friends, and the surrounding area is also decreased (D. King \& Delfabbro, 2018). Thus, studies found the online game addiction can increase the risk of depression and anxiety (D. King \& Delfabbro, 2018), (Puspitosari \& Ananta, 2009), (Zaelani, Setiawati, Maria, \& Lestari, 2019).

In 2019, an intervention study on the mental health issues of high school students has shown online game addiction proportions ranged from $8.6 \%$ to $12 \%$ from 3 different kinds of school categories. This study also pictures a depression experienced by the student from all types of schools. Respondents from intervention schools, control schools, and evaluation schools show the proportion of consecutive depressions at the time of the pre-test was $12.1 \% ; 11.8 \%$; and 13.6\% (Suryaputri et al., 2019). Because of the limited data on the research on the relationship of online game addiction with depression in adolescent has encouraged researchers to conduct this study. The purpose of this study is to analyze the relationship between online game addiction and depression in adolescence.

\section{Method}

This study is a quantitative study using cross-sectional design as a further analysis of the Intervention Study on Mental Health Issues of School Students conducted by the Center for Public Health Efforts in 2019. The population is all students of grade 10 and 11 in six Public High Schools in Bogor Regency, Bogor City, City of Central Jakarta, and South Jakarta in 2019. The selection of schools as the sample was done purposively. To meet the quota for each school, simple random sampling was done to select the sample. The sample in this study was 746 students who took a pre-test. A pre-test is conducted to collect data before the intervention. School approval and informed consent were obtained from the parents of students who were chosen as the sample. The ethical clearance was received from the Health Research Ethics Commission, National Institute of Health Research and Development.

The instruments in this study include a game addiction, a depression questionnaire, and a student general questionnaire. The game addiction questionnaire used was developed by Jap et al. (2013) for the Indonesian population. This instrument has an acceptable range of item-total correlations (ranging from 0.29 to 0.55 ) and an acceptable reliability with alpha $=0.73$. The scoring interpretation used was the range of 14 to 21 to indicate mild addiction where 22 or above may show a moderate and severe level of addiction.

The depression questionnaire, provided in the Indonesian language, was taken from the Patient Health Questionnaire (PHQ-9). It is available at phqscreener.com. Based on the DSM-IV, the PHQ-9 is a validated self-administrated instrument consisting of nine questions to assess major depressive disorders. This study used the original validation of the cut-off point of 10 (Kroenke, Spitzer, \& Williams, 2001). The condition of depression was explored in the last two weeks before data collection was ended. It was included in the category of depressive symptoms if the score $>10$. For use in this study, the PHQ-9 instrument has been tested for validation and reliability in the adolescent age group with a Cronbach alpha $=1$ and the item-total correlation correction value greater than the r-table value (Suryaputri et al., 2019). 
While the student general questionnaire was used to collect the sociodemographic data and several supporting variables such as physical health and learning difficulties experienced by respondents. The stages of data analysis include the process of editing, coding, entry, and cleaning the data. A bivariate analysis was performed using the chi-square test with a significance level of $5 \%$ and a multivariate analysis using multiple logistic regression test.

\section{Results}

The sample size in this study was 746 students (average age 15.4 years \pm 0.7 years). Table 1 shows the results of univariate analysis of depressive events, online game addiction, and the basic characteristics of the sample. The proportion of students who are depressed is $12.9 \%$ and the proportion of online gaming addictions is $10.3 \%$. Almost all students who are tested in this study are in the age under $17(95.5 \%)$ and $56.8 \%$ are female students. The highest proportion of father works in formal sector as much as $66.4 \%$ while for the majority of mother who is not working is $63.3 \%$. In the physical health category, almost all students do not experience the problem (94.5\%). In relation to learning difficulties, there are $14.7 \%$ of students have experienced the difficulties in learning.

Table 1. Basic Characteristics of Students in 6 Public High Schools in 4 Regencies/Cities in Indonesia ( $\mathrm{n}=746)$

\begin{tabular}{|c|c|c|}
\hline Characteristics & Total & Percentage \\
\hline \multicolumn{3}{|l|}{ Age } \\
\hline$-\quad>=17$ years old & 37 & 5.0 \\
\hline$-\quad<17$ years old & 709 & 95.5 \\
\hline \multicolumn{3}{|l|}{ Sex } \\
\hline - Female & 424 & 56.8 \\
\hline - Male & 322 & 43.2 \\
\hline \multicolumn{3}{|l|}{ School origin } \\
\hline - $\quad$ Bogor Regency & 247 & 33.1 \\
\hline - $\quad$ City of Bogor & 247 & 33.1 \\
\hline - $\quad$ Cities of Jakarta & 252 & 33.8 \\
\hline \multicolumn{3}{|l|}{ Father's occupation } \\
\hline - Formal occupation & 495 & 66.4 \\
\hline - Non-Formal occupation & 220 & 29.5 \\
\hline - $\quad$ Unemployed & 31 & 4.2 \\
\hline \multicolumn{3}{|l|}{ Father's level of education } \\
\hline - $\quad$ High & 258 & 34.6 \\
\hline - $\quad$ Middle & 363 & 48.7 \\
\hline - Low & 125 & 16.8 \\
\hline \multicolumn{3}{|l|}{ Mother's occupation } \\
\hline - Formal occupation & 156 & 20.9 \\
\hline - Non-Formal occupation & 118 & 15.8 \\
\hline - $\quad$ Unemployed & 472 & 63.3 \\
\hline \multicolumn{3}{|l|}{ Mother's level of education } \\
\hline - $\quad$ High & 220 & 29.5 \\
\hline - $\quad$ Middle & 379 & 50.8 \\
\hline - $\quad$ Low & 147 & 19.7 \\
\hline \multicolumn{3}{|l|}{ Self-rated of physical health } \\
\hline - $\quad$ Healthy & 705 & 94.5 \\
\hline - There is a complaint on physical health & 41 & 5.5 \\
\hline
\end{tabular}


Learning difficulties

- Currently not

$25 \quad 3.4$

- Sometimes

611

81.9

- Currently yes

110

14.7

\section{Depression}

- No

650

87.1

- Yes

96

12.9

Addicted to online game

- No 669

89.7

- $\quad$ Yes (Mild and higher level)

77

10.3

Based on the results of the bivariate analysis (Table 2), the variables significantly related to depression in high school students include parents' educational level: tertiary and secondary (high) level for father and secondary (middle) level for mother, learning difficulties, and online game addiction issue. The variables of age, gender, father's occupation, mother's occupation, physical health, and school location have shown no significant relationship with the incidence of depression in this study.

Table 2. Relationship between Online Game Addiction and Other Characteristics with Depression in 6 Public High Schools students in 4 Districts/Cities in Indonesia

\begin{tabular}{|c|c|c|c|c|c|c|c|c|}
\hline \multirow{2}{*}{\multicolumn{2}{|c|}{ Characteristics }} & \multicolumn{2}{|c|}{ Not depressed } & \multicolumn{2}{|c|}{ Depressed } & \multirow{2}{*}{ P-Value } & \multirow{2}{*}{ Unadjusted OR } & \multirow{2}{*}{$95 \% \mathrm{CI}$} \\
\hline & & $\mathbf{n}$ & $\%$ & $\mathbf{n}$ & $\%$ & & & \\
\hline \multicolumn{9}{|c|}{ Age } \\
\hline- & $>=17$ years old & 29 & 78.4 & 8 & 21.6 & & Ref & - \\
\hline- & $<17$ years old & 621 & 87.6 & 88 & 12.4 & 0.109 & 0.514 & $0.228-1.159$ \\
\hline \multicolumn{9}{|c|}{ Sex } \\
\hline- & Female & 361 & 85.1 & 63 & 14.9 & & 1.528 & $0.976-2.394$ \\
\hline- & Male & 289 & 89.8 & 33 & 10.2 & 0.064 & Ref & - \\
\hline \multicolumn{9}{|c|}{ School origin } \\
\hline & Bogor Regency & 211 & 85.4 & 36 & 14.6 & 0.382 & Ref & - \\
\hline & City of Bogor & 221 & 89.5 & 26 & 10.5 & 0.176 & 0.690 & $0.402-1.182$ \\
\hline & Cities of Jakarta & 218 & 86.5 & 34 & 13.5 & 0.728 & 0.914 & $0.551-1.515$ \\
\hline \multicolumn{9}{|c|}{ Father's occupation } \\
\hline- & Formal & 430 & 86.9 & 65 & 13.1 & 0.951 & Ref & $0.573-1.495$ \\
\hline- & Non-Formal & 193 & 87.7 & 27 & 12.3 & 0.752 & 0.925 & \\
\hline- & Unemployed & 27 & 87.1 & 4 & 12.9 & 0.971 & 0.980 & $0.332-2.892$ \\
\hline \multicolumn{9}{|c|}{ Father's education } \\
\hline- & High & 218 & 84.5 & 40 & 15.5 & 0.038 & Ref & - \\
\hline- & Middle & 328 & 90.4 & 35 & 9.6 & 0.028 & 0.582 & $0.358-0.944$ \\
\hline- & Low & 104 & 83.2 & 21 & 16.8 & 0.745 & 1.100 & $0.618-1.961$ \\
\hline \multicolumn{9}{|c|}{ Mother's occupation } \\
\hline- & Formal & 134 & 85.9 & 22 & 14.1 & 0.079 & Ref & - \\
\hline- & Non-Formal & 96 & 81.4 & 22 & 18.6 & 0.312 & 1.396 & $0.731-2.664$ \\
\hline- & Unemployed & 420 & 89.0 & 52 & 11.0 & 0.301 & 0.754 & $0.442-1.288$ \\
\hline
\end{tabular}




\begin{tabular}{|c|c|c|c|c|c|c|c|c|}
\hline \multicolumn{9}{|c|}{ Mother's education } \\
\hline- & High & 183 & 83.2 & 37 & 16.8 & 0.051 & Ref & - \\
\hline- & Middle & 341 & 90 & 38 & 10 & 0.017 & 0.551 & $0.339-0.897$ \\
\hline- & Low & 126 & 85.7 & 21 & 14.3 & 0.515 & 0.824 & $0.461-1.475$ \\
\hline \multicolumn{9}{|c|}{ Self-rated of physical health } \\
\hline- & Healthy & 617 & 87.5 & 88 & 12.5 & & Ref & - \\
\hline- & One or more complaint & 33 & 80.5 & 8 & 19.5 & 0.196 & 1.700 & $0.761-3.798$ \\
\hline \multicolumn{9}{|c|}{ Learning difficulties } \\
\hline- & Currently not & 24 & 96 & 1 & 4 & 0.000 & Ref & - \\
\hline- & Sometimes & 551 & 90.2 & 60 & 9.8 & 0.351 & 2.613 & $0.347-19.662$ \\
\hline- & Currently yes & 75 & 68.2 & 35 & 31.8 & 0.020 & 11.2 & $1.456-86.154$ \\
\hline \multicolumn{9}{|c|}{ Addicted to online game } \\
\hline & No & 589 & 88 & 80 & 12 & & Ref & \multirow{2}{*}{$1.062-3.512$} \\
\hline & Yes & 61 & 79.2 & 16 & 20.8 & 0.031 & 1.931 & \\
\hline
\end{tabular}

Based on the bivariate analysis using simple logistic regression test, there are eight variables with $p$-value $<0.25$ included in the multivariate analysis: level of online game addiction, age, gender, school origin, father's education, mother's occupation, mother's education, health physical, and learning difficulties. The final result of the multivariate analysis is presented in table 3 .

Table 3. Final Model of Multivariate Analysis

\begin{tabular}{|c|c|c|c|c|c|c|}
\hline \multirow{2}{*}{ Variables } & \multirow{2}{*}{$\mathrm{B}$} & \multirow{2}{*}{ S.E. } & \multirow{2}{*}{ Sig. } & \multirow{2}{*}{ adjustedOR } & \multicolumn{2}{|c|}{$95 \%$ C.I. } \\
\hline & & & & & lower & upper \\
\hline \multicolumn{7}{|l|}{ Online Game Addiction } \\
\hline $\begin{array}{l}\text { - Yes (mild dan higher } \\
\text { level) }\end{array}$ & 0.893 & 0.338 & 0.008 & 2.442 & 1.259 & 4.735 \\
\hline \multicolumn{7}{|l|}{ Sex: } \\
\hline - Female & 0.730 & 0.254 & 0.004 & 2.075 & 1.260 & 3.417 \\
\hline \multicolumn{7}{|l|}{ Learning difficulties: } \\
\hline - $\quad$ Sometimes & 0.858 & 1.036 & 0.408 & 2.357 & 0.310 & 17.945 \\
\hline - $\quad$ Always & 2.398 & 1.047 & 0.022 & 11.001 & 1.413 & 85.636 \\
\hline Young age $<17$ th & -0.870 & 0.443 & 0.049 & 0.419 & 0.176 & 0.997 \\
\hline
\end{tabular}

From the final model, it can be seen that female students who are gaming addict, age younger than 17, and have learning difficulties are likely to be depressed in their puberty phase. The table also shows the order of the variables from the highest to the lowest OR: learning difficulties, online game addiction, gender, and age. Even though learning difficulties resulted in a high OR, the $95 \%$ CI range is quite wide. Young age $(<17$ years) can be included as a preventive factor against depression. Adolescents who are addicted to online games in both mild and severe categories have 2.4 times chance to experience depression compared to those who are not addicted to online games. This is after being controlled by age, sex, school origin, father's education, mother's occupation, mother's education, physical health, and learning difficulties.

\section{Discussion}

This study found the proportion of online game addiction of $10.3 \%$ which is very close to the results of previous studies with a prevalence of $10.15 \%$ in school students in Indonesia (Jap et al., 2013). In addition, this study also found 96 students (12.9\%) experienced depression. The proportion of depressive events in this study is smaller 
than the study conducted by Ariyani in 2012 at $28.6 \%$ (Sofi, 2012). But when compared with previous studies in junior high school students, the proportion is higher where the emergence of extreme depression is equal to $7.9 \%$ (Zaelani et al., 2019). Data of Indonesia Basic Health Research (RISKESDAS) in 2018 shows national depression prevalence is $6.1 \%$ of people aged $>15$ years (Badan Penelitian dan Pengembangan Kesehatan Kementerian RI, 2019). However, this study reveals the depression proportion is much higher compared to the national prevalence of depression.

Based on multivariate analysis, there is a relationship between learning difficulties and the incidence of depression. A study observing 658 Finnish adolescence revealed that learning difficulties predict depression, with the intermediate factors involves learning disabilities, fatigue feeling and feeling overwhelmed to meet the academic achievement at school (Kiuru, Leskinen, Nurmi, \& Salmela-Aro, 2011). In another study, a female adolescent with learning difficulties has a significant relationship with anxiety and depression (Ashraf \& Najam, 2015). Based on data from the McGill Group on Suicide Studies in Canada, factors of academic failure include learning difficulties, low academic performance, and repeating class are associated with suicides before age 35 (Ligier et al., 2020). According to Diannovinina's study in 2018, the majority of research subjects who were depressed had problems related to learning achievement at 53\% (Dianovinina, 2018).

This study also found students who are addicted to online games are associated with the incidence of depression. This is in line with previous studies that showed there is a relationship between addiction to playing online games with depression where the higher the level of online gaming addiction, the higher the level of depression happen in adolescence student (Zaelani et al., 2019). In 2012, a study found an individual with online gaming addiction has a 1.61 times greater risk of depression than those who are not addicted to online game (OR 1.61; 95\% CI 0.30-8.69) (Sofi, 2012). Several studies have been conducted to explore how online game addiction is related to depression.

The study of human brain function by imaging the brain showed that abnormalities in thickness in some areas of the brain such as the left precursor cortex, precuneus, middle frontal cortex, inferior temporal and middle temporal cortex in late adolescence are related to the pathophysiology that underlying online game addiction (Yuan et al., 2013) and interruption on brain function to connect due to internet gaming disruption (Liu et al., 2018). Psychologically, online game addiction has a relationship with mental health problems that are interrelated to one another such as depression, loneliness, and social anxiety (Wang, Sheng, Wang, \& Wang, 2019). Other studies reveal strong engagement in gaming can cause an individual to skip sleep, hobbies, and social interactions. Those who are game addicts would prefer online interaction rather than face-to-face interactions (Hellström, Nilsson, Leppert, \& Åslund, 2015). For that reason, adolescences who are addicted to online games have a higher risk of health and psychological problems compared to those who are not addicted to online games (Achab et al., 2011). Another study of brain imaging found social interaction and interpersonal incompetence in online game addiction. It becomes a serious problem if this happens to adolescents as they are in the development phase physically and emotionally. Adolescents with gaming addiction have also been proven to deal with maladaptive behavior such as denial and behavioral disengagement (Schneider, King, \& Delfabbro, 2018). If this is not treated properly then adolescents will not have the ability to deal with problems which likely lead to more severe psychological problems.

Another interesting result that is consistent with prior research is that adolescent females are having a higher risk of depression (Angst et al., 2002; Picco, Subramaniam, Abdin, Vaingankar, \& Chong, 2017; Van de Velde, Bracke, Levecque, \& Meuleman, 2010). Scholars have significantly examined the issue of puberty among both males and females. Puberty is a critical stage in human development, physical and hormonal changes can psychologically affect the adolescent to exhibit traits such as mood swings and overly sensitive feelings (Girgus \& Yang, 2015). The change of ways of thinking can trigger adolescent girls to overthinking and shuts down their willingness to build confidence by trying and failing (Krause et al., 2018). Additionally, girls who went through early menarche than most were more likely to become depressed, and their symptoms were also more severe in adolescence, the study found (Sequeira, Lewis, Bonilla, Smith, \& Joinson, 2017). Females are also found to have greater levels of negative affect and depression related to interpersonal stress than do males since many of them struggle with low self-awareness and need of social acceptance (Conley, Rudolph, \& Bryant, 2013). Adolescent females are more vulnerable to create mental and emotional health issues during puberty since they are more aware of the physical changes of the body which may lead to low self-esteem and stress (Murray, Rieger, \& Byrne, 2018).

Although various studies show that adolescent girls have a greater risk of experiencing depression, some ways can be helpful to reduce the risk of depression in the adolescence period such as having an orientation toward goals, building self-confidence, and social abilities, and social support (Askeland et al., 2020); strong family ties during puberty period can help ward off depression (Piko, Kovacs, \& Fitzpatrick, 2009); perceiving thoughts and 
emotions would take them toward self-awareness (Eberhart, Shih, Hammen, \& Brennan, 2006); school support helps develop social acceptance and self-value (Langille, Rasic, Kisely, Flowerdew, \& Cobbett, 2012). However, these factors become a limitation in the research conducted because it does not examine these factors, so it requires deeper research in the future to include factors to prevent depression for both adolescent females and males.

This study also reveals young adolescents, $<17$ years, tend to experience depression. The increase in depression reaches its peak when adolescents in males and females are in their mid and late adolescence (ages 15 to 18 years). Due to a higher number of depression cases, this period is critical for adolescents and be more vulnerable to depression (Hankin et al., 1998). Other studies show slightly different results, symptoms of depression are slightly low at the age of 12 years to 14 years then begin to rise at the age of 14-17 years and decline at 21 years (Rawana \& Morgan, 2014). The results of longitudinal studies from the National Longitudinal Survey of Children and Youth in Canada provides a more dynamic picture as depressive symptoms increase from early to middle adolescence (12-17 years), and go down when entering the period of late adolescence to young adulthood (18-24 years) but increase again until the late young adult period (25 years) (Ferro, Gorter, \& Boyle, 2015). From these studies, it can be seen that the middle adolescent period (14-17 years) is a significant period that needs attention due to the emergence of depression in adolescents.

\section{Conclusion}

Online games addiction, learning difficulties, female gender, and early adolescence are significantly related to the incidence of depression in high school students from 6 schools in 4 districts/cities in Indonesia. Addiction to online games can have a negative impact on the physical, social-interpersonal relationships, and mental health of adolescents. Schools are the best institutions that can be used as the main step in screening depression with various risk factors that exist in schools.

Recommendation from this study includes the need to provide mental services to overcome online gaming addiction for students. In addition, special attention needs to be given to students who have learning difficulties or low academic grades. Motivation or counseling is needed to prevent school stress. Schools and parents need to be cooperative and informative in increasing mental health literacy so that various risk factors cause mental health problems can be anticipated.

\section{Author's Contribution}

NS, PPA, and IYS have equal contribution in strengthening the study ideas, conducting data analysis, discussion, and writing the manuscript. Conceptualization: NS, PPA. Data curation: PPA. Formal analysis: PPA, NS. Methodology: NS, PPA, IYS. Writing-original draft: NS. Writing - review \&editing: PPA, IYS. All authors approved the final version of the manuscript.

\section{Acknowledgments}

Financial support for this research was provided by the National Institute of Health Research and Development, Indonesia, Grant for Intervention Study on Mental Health Issue of School Student in the year 2019. We are grateful for the supports from the Head of the Center for Public Health Efforts, the Head of the PTM and Keswa Subdivisions, and the Research Team for School-Based Mental Health Intervention Studies. Besides that, we do not forget to thank Dr. Tjibeng Jap Ph.D. \& Dr. Edo Sebastian Jaya and his team for permitting to use the instrument adaptations.

\section{Competing Interests Statement}

The authors declare that there are no competing or potential conflicts of interest.

\section{References}

Achab, S., Nicolier, M., Mauny, F., Monnin, J., Trojak, B., Vandel, P., ... \& Haffen, E. (2011). Massively multiplayer online role-playing games: comparing characteristics of addict vsnon-addict online recruited gamers in a French adult population. BMC psychiatry, 11(1), 144. https://doi.org/10.1186/1471-244X-11-144

Adams, E. (2009). Fundamentals of Game Design (2nd ed.). Berkeley, CA: New Riders.

Angst, J., Gamma, A., Gastpar, M., Lépine, J. P., Mendlewicz, J., \& Tylee, A. (2002). Gender differences in depression: Epidemiological findings from the European DEPRES I and II studies. European Archives of Psychiatry and Clinical Neuroscience, 252(5), 201-209. https://doi.org/10.1007/s00406-002-0381-6

Ashraf, F., \& Najam, N. (2015). Comorbidity of Anxiety Disorder and Major Depression among Girls with Learning Disabilities. Pakistan Journal of Medical Research PakJ Med Res, 54(4).

Askeland, K. G., Bøe, T., Breivik, K., la Greca, A. M., Sivertsen, B., \& Hysing, M. (2020). Life events and 
adolescent depressive symptoms: Protective factors associated with resilience. PLoS ONE, 15(6 June), 1-16. https://doi.org/10.1371/journal.pone.0234109

Badan Penelitian dan Pengembangan Kesehatan Kementerian RI. (2019). Laporan Nasional Riskesdas 2018. Jakarta.

Conley, C. S., Rudolph, K. D., \& Bryant, F. B. (2013). Explaining the Longitudinal Association Between Puberty and Depression. Developmental Psychopathology, 24(2), 691-701. https://doi.org/10.1017/S0954579412000259.Explaining

Dianovinina, K. (2018). Depresi pada Remaja: Gejala dan Permasalahannya. Jurnal Psikogenesis, 6(1), 69-78. https://doi.org/10.24854/jps.v6i1.634

Eberhart, N. K., Shih, J. H., Hammen, C. L., \& Brennan, P. A. (2006). Understanding the sex difference in vulnerability to adolescent depression: An examination of child and parent characteristics. Journal of Abnormal Child Psychology, 34(4), 495-508. https://doi.org/10.1007/s10802-006-9020-4

Fam, J. I. A. Y. (2018). Prevalence of internet gaming disorder in adolescents : A meta-analysis across three decades. Scandinavian Journal of Psychology. https://doi.org/10.1111/sjop.12459

Ferro, M. A., Gorter, J. W., \& Boyle, M. H. (2015). Trajectories of depressive symptoms during the transition to young adulthood: The role of chronic illness. Journal of Affective Disorders, 174, 594-601. https://doi.org/10.1016/j.jad.2014.12.014

Gentile, D., Bailey, K., Bavelier, D., Brockmyer, J., Cash, H., Coyne, S., .. \& Y Young, K. (2017). Internet Gaming Disorder in Children and Adolescents. Pediatrics, 140(s2), s81-s85. https://doi.org/10.1542/peds.2016-1758H

Girgus, J. S., \& Yang, K. (2015). Gender and depression. Current Opinion in Psychology, 4, 53-60. https://doi.org/10.1016/j.copsyc.2015.01.019

Hankin, B. L., Abramson, L. Y., Moffitt, T. E., Angell, K. E., Silva, P. A., \& McGee, R. (1998). Development of depression from preadolescence to young adulthood: Emerging gender differences in a 10-year longitudinal study. Journal of Abnormal Psychology, 107(1), 128-140. https://doi.org/10.1037/0021-843X.107.1.128

Hellström, C., Nilsson, K. W., Leppert, J., \& Åslund, C. (2015). Effects of adolescent online gaming time and motives on depressive, musculoskeletal, and psychosomatic symptoms. Upsala Journal of Medical Sciences, 120(4), 263-275. https://doi.org/10.3109/03009734.2015.1049724

Hu, J., Zhen, S., Yu, C., Zhang, Q., \& Zhang, W. (2017). Sensation seeking and online gaming addiction in adolescents: A moderated mediation model of positive affective Associations and Impulsivity. Frontiers in Psychology, 8(MAY), 1-8. https://doi.org/10.3389/fpsyg.2017.00699

Jannah, N., Mudjiran, M., \& Nirwana, H. (2015). Hubungan kecanduan game dengan motivasi belajar siswa dan implikasinya terhadap Bimbingan dan Konseling. Konselor, 4(4), 200-207. https://doi.org/10.24036/02015446473-0-00

Jap, T., Tiatri, S., Jaya, E. S., \& Suteja, M. S. (2013). The Development of Indonesian Online Game Addiction Questionnaire. PLOS ONE, 8(4), e61098. Retrieved from https://doi.org/10.1371/journal.pone.0061098

King, D., \& Delfabbro, P. (2018). Internet Gaming Disorder: Theory, Assessment, Prevention, and Treatment (1st Edition). (T. Frank, Ed.), Internet Gaming Disorder: Theory, Assessment, Treatment, and Prevention (1st ed.). Academic Press. https://doi.org/10.1016/C2016-0-04107-4

King, D. L., \& Delfabbro, P. H. (2014). The cognitive psychology of Internet gaming disorder. Clinical Psychology Review, 34(4), 298-308. https://doi.org/10.1016/j.cpr.2014.03.006

Kiuru, N., Leskinen, E., Nurmi, J. E., \& Salmela-Aro, K. (2011). Depressive symptoms during adolescence: Do learning difficulties matter? International Journal of Behavioral Development, 35(4), 298-306. https://doi.org/10.1177/0165025410396764

Krause, E. D., Vélez, C. E., Woo, R., Hoffmann, B., Freres, D. R., Abenavoli, R. M., \& Gillham, J. E. (2018). Rumination, Depression, and Gender in Early Adolescence: A Longitudinal Study of a Bidirectional Model. Journal of Early Adolescence, 38(7), 923-946. https://doi.org/10.1177/0272431617704956

Kroenke, K., Spitzer, R. L., \& Williams, J. B. W. (2001). The PHQ-9: validity of a brief depression severity measure. $J$ Gen Intern Med, 16(9), 606-613. PMID: 11556941; PMCID: PMC1495268. https://doi.org/10.1046/j.1525-1497.2001.016009606.x 
Kuss, D. J., \& Griffiths, M. D. (2012). Adolescent online gaming addiction. Education and Health, 30(1), 15-17.

Lam, L. T. (2014). Internet Gaming Addiction, Problematic Use of the Internet, and Sleep Problems : A Systematic Review. https://doi.org/10.1007/s11920-014-0444-1

Langille, D., Rasic, D., Kisely, S., Flowerdew, G., \& Cobbett, S. (2012). Protective associations of school connectedness with risk of depression in nova scotia adolescents. Canadian Journal of Psychiatry, 57(12), 759-764. https://doi.org/10.1177/070674371205701208

Ligier, F., Giguère, C.-E., Notredame, C.-E., Lesage, A., Renaud, J., \& Séguin, M. (2020). Are school difficulties an early sign for mental disorder diagnosis and suicide prevention? A comparative study of individuals who died by suicide and control group. Child and Adolescent Psychiatry and Mental Health, 14(1), 1-9. https://doi.org/10.1186/s13034-019-0308-X

Liu, L., Yao, Y. W., Li, C. shan R., Zhang, J. T., Xia, C. C., Lan, J., ... Fang, X. Y. (2018). The comorbidity between internet gaming disorder and depression: Interrelationship and neural mechanisms. Frontiers in Psychiatry, 9(APR), 1-10. https://doi.org/10.3389/fpsyt.2018.00154

Manuputty, J. C., Sekeon, S. A. S., Kandou, G. D., Kesehatan, F., Universitas, M., \& Ratulangi, S. (2019). Hubungan Antara Kecanduan Bermain Game Online dengan Kualitas Tidur pada Gamer Online Pengguna Komputer di Warung Internet M2G Supernova Malalayang. Jurnal KESMAS, 8(7), 61-66.

Murray, K., Rieger, E., \& Byrne, D. (2018). Body image predictors of depressive symptoms in adolescence. Journal of Adolescence, 69(May), 130-139. https://doi.org/10.1016/j.adolescence.2018.10.002

Picco, L., Subramaniam, M., Abdin, E., Vaingankar, J. A., \& Chong, S. A. (2017). Gender differences in major depressive disorder: Findings from the Singapore mental health study. Singapore Medical Journal, 58(11), 649-655. https://doi.org/10.11622/smedj.2016144

Piko, B. F., Kovacs, E., \& Fitzpatrick, K. M. (2009). What makes a difference? Understanding the role of protective factors in Hungarian adolescents' depressive symptomatology. European Child and Adolescent Psychiatry, 18(10), 617-624. https://doi.org/10.1007/s00787-009-0022-y

Puspitosari, W. A., \& Ananta, L. (2009). Hubungan antara Kecanduan Online Game dengan Depresi Correlation between Online Game Addiction with Depression. Mutiara Medika, 9(1), 50-56.

Rawana, J. S., \& Morgan, A. S. (2014). Trajectories of Depressive Symptoms from Adolescence to Young Adulthood: The Role of Self-esteem and Body-Related Predictors. Journal of Youth and Adolescence, 43(4), 597-611. https://doi.org/10.1007/s10964-013-9995-4

Schneider, L. A., King, D. L., \& Delfabbro, P. H. (2018). Maladaptive Coping Styles in Adolescents with Internet Gaming Disorder Symptoms. International Journal of Mental Health and Addiction, 16(4), 905-916. https://doi.org/10.1007/s11469-017-9756-9

Sequeira, M. E., Lewis, S. J., Bonilla, C., Smith, G. D., \& Joinson, C. (2017). Association of timing of menarche with depressive symptoms and depression in adolescence: Mendelian randomisation study. British Journal of Psychiatry, 210(1), 39-46. https://doi.org/10.1192/bjp.bp.115.168617

Sofi, A. (2012). Hubungan kecanduan online game dengan depresi pada remaja laki-laki pengunjung game centre di Kelurahan Jebres. Universitas Sebelas Maret.

Suryaputri, I. Y., Mubasyiroh, R., Idaiani, S., Salimar, Nurhotimah, E., Sitorus, N., ... Permanasari, Y. (2019). Studi Intervensi Kesehatan Jiwa Berbasis Sekolah. Jakarta.

Taechoyotin, P., Tongrod, P., Thaweerungruangkul, T., \& Towattananon, N. (2020). Prevalence and associated factors of internet gaming disorder among secondary school students in rural community, Thailand : a cross sectional study. BMC Research Notes, 1-7. https://doi.org/10.1186/s13104-019-4862-3

Van de Velde, S., Bracke, P., Levecque, K., \& Meuleman, B. (2010). Gender differences in depression in 25 European countries after eliminating measurement bias in the CES-D 8. Social Science Research, 39(3), 396-404. https://doi.org/10.1016/j.ssresearch.2010.01.002

Wang, H. Z., Sheng, J. R., \& Wang, J. L. (2019). The association between mobile game addiction and depression, social anxiety, and loneliness. Frontiers in public health, 7, 247. https://doi.org/10.3389/fpubh.2019.00247

Wiguna, G. Y., \& Herdiyanto, Y. K. (2018). Coping pada Remaja yang Kecanduan Bermain Game Online. Jurnal Psikologi Udayana, 5(2), 450. https://doi.org/10.24843/jpu.2018.v05.102.p15

World Health Organization. (2018). Gaming disorder. Retrieved July 2, 2020, from 
https://www.who.int/news-room/q-a-detail/gaming-disorder

Yuan, K., Cheng, P., Dong, T., Bi, Y., Xing, L., Yu, D., ... Tian, J. (2013). Cortical Thickness Abnormalities in Late Adolescence with Online Gaming Addiction. PLoS ONE, 8(1). https://doi.org/10.1371/journal.pone.0053055

Zaelani, A. F., Setiawati, O. R., \& Lestari, S. M. P. (2019). Hubungan Kecanduan Bermain Game Online Dengan Depresi Pada Siswa SMP. Jurnal Psikologi Malahayati, 1(2), 35-41. https://doi.org/10.33024/jpm.v1i2.1868

\section{Copyrights}

Copyright for this article is retained by the author(s), with first publication rights granted to the journal.

This is an open-access article distributed under the terms and conditions of the Creative Commons Attribution license (http://creativecommons.org/licenses/by/4.0/). 